\title{
DROUGHT TOLERANCE INDICES OF SELECTED LANDRACES AND BREAD WHEAT (TRITICUM AESTIVUM L.) GENOTYPES DERIVED FROM SYNTHETIC WHEATS
}

\author{
AKTAŞ, H. \\ Mardin Artuklu University Vocational School of Kizlltepe, Mardin, Turkey \\ E-mail: h_aktas47@hotmail.com \\ Phone: +904822152503 \\ (Received $14^{\text {th }}$ May 2016; accepted $22^{\text {nd }}$ Jul 2016)
}

\begin{abstract}
The present study was performed to determine performance of selected four synthetic derived bread wheat genotypes, four bread wheat landraces and four modern wheat genotypes under rain-fed and supplemented irrigation experiments based on randomized complete block design with four replications at GAP International Agricultural Research and Training Center, Diyarbakır, Turkey in 2013-2014 and 2014-2015 growing seasons. According to results of pairwise correlation and biplot analysis, significant and positive correlation was observed between grain yield in stress condition (Ys) and stress tolerant index (STI), geometric mean productivity (GMP), mean productivity (MP), harmonic productivity (HM), yield stability index (YSI), yield index (YI), drought resistance index (DI) and stress non-stress production index (SNPI) indicating these indices can be used as parameters for evaluating drought tolerant genotypes. Negative correlation between grain yield in stress (Ys) with SSI and no correlation with TOL indicated that these indices should be used in severe drought conditions for screening genotypes. Number seed in spike (NSS), plant height (PH) and thousand kernel weight (TKW) correlated with grain yield in stress conditions (Ys) according to biplot analysis, also genotypes with lower reduction relating to these traits had higher yield in stress conditions. According to results SEN-DER genotypes G7, G10, landrace group genotype G11 (Sorlk) were determined as the most tolerant genotypes to be used to improve drought tolerant varieties, while modern wheat genotypes G4 (Ceyhan-99) and G2 (Tekin) were high productive in irrigation conditions and low productive in rain-fed conditions.
\end{abstract}

Keywords: abiotic stress, grain yield, spad, grain number, Triticum aestivum L, correlation, biplot

\section{Introduction}

Wheat (Triticum aestivum L.) is the main human consumption that provides food for $35 \%$ of world population (Nouri et al., 2011). Increasing world's population expected to hit $\sim 9$ billion by 2050 . It is expected that wheat's demand will increase by $40 \%$ by the year 2030 (Dixon et al., 2008). It would aggravate the environmental impacts by intensifying the water and land conflicts. Thus, a congruent effort for mounting consumptive needs with environmental protection seems obligatory (Koh-Banerjee et al., 2004).

Environmental stresses are the major constraints to the world food production. Although, wheat is probably the only cereal crop that can survive large range of temperature, altitudes and water availability ranges (Reynolds and Rebetzke, 2011), its production fluctuates from year to year and from location to location due to unpredicted climatic conditions. Therefore, improvement of wheat production under drought has become a primary objective of breeding programs around the globe particularly in arid and semi-arid regions. Food security in present and future will rely on the improved resistance to drought and high yielding cultivars (Ogbonnaya et al., 2008).

Traits that related to drought genetic resistance is very limited because of lack of genetic variability in modern wheat cultivars. Due to land limitations, the enhancement of wheat production must come from higher absolute yields by increasing efforts in 
plant breeding along with biotechnological tools and expanded genetic diversity (Rajaram, 2001). For example in the past 20 years CIMMYT (International Maize and Wheat Improvement Center) have created synthetic hybrid wheats (SHW) to incorporate novel resistance genes/traits for biotic and abiotic stress in modern wheat cultivars (Ogbonnaya et al., 2008). This exiting new resource is created by artificially crossing durum wheat (Triticum turgidum; $2 \mathrm{n}=4 \mathrm{x}=28 \mathrm{AABB}$ ) with Aegilops tauschii $(2 \mathrm{n}=2 \mathrm{x}=14 \mathrm{DD})$. Also, researcher have screened landrace to determine drought tolerant traits. Wheat landraces have a good adaption in drought stress condition but their yield potential under favorable conditions is limited because of lodging sensitivity, and low nitrogen use efficiency, thus their using in Turkey National Wheat programs has been neglected (Akçura, 2001b).

Wheat production of $65-70 \%$ in Turkey depends on rainfall conditions, where drought stress occurs most often, thus improving and determination of drought tolerant wheat genotypes is very important. Determination of drought tolerant genotypes in breeding programs is also very complicate since the lack of drought tolerant indicators. Genotypes have been evaluated in dry and normal conditions to estimate drought resistance level of genotypes. Mathematical relationship based on grain yield loss between favorable and stress conditions provide several selection indices to determine drought resistance difference between genotypes. These indices measure productivity of genotypes under dry condition that are indicator for drought tolerance and used in investigations such as TOL (Tolerance), SSI (Stress susceptibility index), MP (Mean productivity) and STI (Stress tolerant index).

The aim of present study was to (i) investigate drought tolerant of synthetic hexzaploid wheat, landraces and modern bread wheat genotypes under rain-fed conditions of Southeast Anatolian Region of Turkey, (ii) determine the efficiency of tolerance indices to grouped bread wheat genotypes into sensitive and tolerant (iii) investigate of relationships between tolerance indices and also relation between investigated traits and grain yield.

\section{Material and Methods}

Four modern bread wheat genotypes that largely grown in southeast of Turkey, four bread wheat derived from synthetic hexzaploid wheat and four bread wheat landrace were chosen for study based on their yield performance in regional yield trials. The origin and status of genotypes are given (Table 1). Experiments were conducted at GAP International Agriculture and Training Center, Diyarbakır province under supplemented irrigation and rain-fed conditions during both 2013-2014 and 2014-2015 growing seasons. The experimental station of GAP International Agricultural Research and Training Center is located $37^{\circ} 55^{\prime} 36^{\prime \prime} \mathrm{N} 40^{\circ} 13^{\prime} 49^{\prime \prime} \mathrm{E}$ at $640 \mathrm{~m}$ above sea level. According to soil analysis, the soil of experimental area was clay-loam, $\mathrm{pH}$ of 8.1, content of organic matter $1.75 \%$, ECe of $1.98 \mathrm{dSm}^{-1}, \mathrm{CaCO}_{3}$ of $15.1 \mathrm{~g} \mathrm{~kg}^{-1}$ and suitable P for plant $18.86 \mathrm{~kg} \mathrm{ha}^{-1}$. Climatic condition of Diyarbakır province is characterized by a semi-arid climate (humid winters and dry summers). Rainfall distribution is fluctuate in Diyarbakır province and most of precipitation occurs between November and May, and precipitation of long term is $455 \mathrm{~mm}$. Annual rainfall were 365 and $445 \mathrm{~mm}$ during 2013-2014 and 2014-2015 growing seasons respectively in Diyarbakır. Genotypes were planted by a sowing-machine into 4 replication with randomized complete block design (RCBD) experiments. Plots were 6 rows, 5 meters long, and spaced $20 \mathrm{~cm}$. Plots were 
seeded $200 \mathrm{~kg} \mathrm{ha}^{-1}$ and fertilized with $60 \mathrm{~kg} \mathrm{ha}^{-1}$ Urea and $120 \mathrm{kgha}^{-1}$ DAP fertilizers. Herbicide, Topic-15 WG at $33 \mathrm{~g}$ a.i. $\mathrm{ha}^{-1}$ were used for weeds control in all experiments. $110 \mathrm{~mm}$ water were applied for irrigated plots at tillering $(55 \mathrm{~mm})$ and booting stages (55 mm).

Grain yield (GY) explained as ton per hectare $\left(\mathrm{t} \mathrm{ha}^{-1}\right)$, and the other traits number of spike $\mathrm{m}^{-2}(\mathrm{NS})$, number of grains spike (NSS) plant height (PH), days to heading (HD), thousand kernel weight (TKW), protein content (PRT), and spad values (SPADchlorophyll content) were recorded.

For drought tolerance indices below formulas were used as follow:

Stress susceptibility index $($ Fernandez, 1992) $=\mathrm{SSI}=(1-(\mathrm{Ys} / \mathrm{Yp})) / \mathrm{SI}$

Stress tolerance index $\left(\right.$ Fernandez, 1992) $=\mathrm{STI}=(\mathrm{Yp} * \mathrm{Ys}) / \overline{\mathrm{Y}} \mathrm{p}^{2}$

Tolerance $($ Hossain et al., 1990) $=$ TOL $=$ Yp-Ys

Geometric mean productivity $($ Fernandez, 1992) $=\mathrm{GMP}=\sqrt{(\mathrm{Yp} * \mathrm{Ys})}$

Mean Productivity $($ Rosielle and Hambline, 1981) $=\mathrm{MP}=(\mathrm{Yp}+\mathrm{Ys}) / 2$

Harmonic Mean (Chakherchaman et al., 2009) $=\mathrm{HM}=2 *(\mathrm{Yp} * \mathrm{Ys}) /(\mathrm{Yp}+\mathrm{Ys})$

Yield stability index (Bouslama and Schapaugh, 1984) $=$ YSI $=$ Ys/Yp

Yield index $($ Gavuzzi et al., 1997) $=\mathrm{YI}=\mathrm{Ys} / \overline{\mathrm{Y}} \mathrm{s}$

Drought resistance index $(\mathrm{Lan}, 1998)=\mathrm{DI}=\mathrm{Ys} \times(\mathrm{Ys} / \mathrm{Yp}) / \overline{\mathrm{Y}} \mathrm{s}$

Abiotic tolerance index (Moosavi et al., 2008) $=\mathrm{ATI}=[(\mathrm{Yp}-\mathrm{Ys}) /(\overline{\mathrm{Y}} \mathrm{p} / \overline{\mathrm{Y}} \mathrm{s})] \mathrm{x}$ $[\sqrt{\mathrm{Yp} * \mathrm{Ys}}]$

Stress susceptibility percentage index (Moosavi et al., 2008) $=$ SSPI $=[$ Yp-Ys/2(Ȳp) $] \mathrm{x}$ 100

Stress non-stress production index (Moosavi et al, 2008) $=$ SNPI $=$ $\sqrt{(\mathrm{Yp}+\mathrm{Ys}) /(\mathrm{Yp}-\mathrm{Ys})}] \times[\sqrt{\mathrm{Yp} \times \mathrm{Ys} \times \mathrm{Ys}}]$

Where, Yp is the yield under non-stress; Ys the yield under stress condition; $\bar{Y} p$ is the mean yield of all genotypes; $\bar{Y} s$ is the mean yield of all genotypes; and

$\mathrm{SI}=1-(\overline{\mathrm{Y}} \mathrm{s} / \overline{\mathrm{Y}} \mathrm{p})$

Combined analysis of variance based on Random Complete Block Design (RCBD), correlation and biplot analyses were carried out using GenStat $12^{\text {th }}$ (Genstat, 2009). Comparison of the means were calculated by LSD test $(\mathrm{p}<0.01$ and $\mathrm{p}<0.05)$. 
Table 1. Wheat genotypes with their code, cross and origin

\begin{tabular}{|c|c|c|c|c|}
\hline Genotypes & Code & Status & Cross & Origin \\
\hline Asure & G1 & Landrace & - & \\
\hline Tekin & $\mathrm{G} 2$ & Cultivar & Wbll1*2/Tukuru & Turkey-CIMMYT \\
\hline Sagitario & G3 & Cultivar & - & ITALY \\
\hline Ceyhan-99 & G4 & Cultivar & Bjy/Coc (Cimmyt) & Turkey-CIMMYT \\
\hline Karakılçık & $\begin{array}{l}\text { G5 } \\
\text { G6 }\end{array}$ & Landrace & $\overline{-}_{\text {Rrv/Ww 15/3/Bi/2Bon }}$ & Turkey-CIMMYT \\
\hline Karacadağ-98 & G7 & Cultivar & $\begin{array}{l}\text { Rrv/Ww.15/3/Bj/2Bon } \\
\text { //4/Nac } \\
\text { Croc 1/Ae. squarrosa }\end{array}$ & Turkey-CIMMYT \\
\hline Vorobey & G8 & Cultivar (SEN-DER) & $\begin{array}{l}\text { (224)//Opata/3/Pastor } \\
\text { Pastor x Altar } 84 / \text { Aeg1lops }\end{array}$ & CIMMYT \\
\hline Sokoll & G9 & Line (SEN-DER) & $\begin{array}{l}\text { Squarrosa (Taus)//Opata } \\
\text { Altar 84/Ae.Squarrosa } \\
(219) / / 2 * \text { Seri/4/Pfau/Bow// }\end{array}$ & CIMMYT \\
\hline SEN-DER 2. & G10 & Line (SEN-DER) & $\begin{array}{l}\text { Vee\#9/3/Ducula } \\
\text { Croc_1/Ae.Squarrosa(205)// }\end{array}$ & CIMMYT \\
\hline SEN-DER 3. & & Line (SEN-DER) & Kauz/3/Pastor & CIMMYT \\
\hline Sorık & G11 & Landrace & - & Turkey \\
\hline Bejireş & G12 & Landrace & - & Turkey \\
\hline
\end{tabular}

\section{Results}

\section{Evaluation of Grain Yield and Investigated Traits}

According to combined ANOVA analysis of Ys, Yp and drought tolerance indices, there were highly significant differences $(\mathrm{p}<0.01$ or $\mathrm{p}<0.05)$ among environments, genotypes, and GE interaction for grain yield and investigated another all traits (Table 2). These results indicating presence of consideration variability in irrigated and rain-fed conditions for investigated traits such as grain yield (GY), thousand kernel weight (TKW), plant height (PH), number of spike in square meter (NS), number seed in spike (NSS). Also, drought stress caused decreasing of GY, TKW, PH, NS and NSS values (Table 4). Mean grain over two year yield in stress condition ranged from 3.46 to $5.50 \mathrm{t}$ $\mathrm{ha}^{-1}$ and from 4.56 to $6.80 \mathrm{t} \mathrm{ha}^{-1}$ in irrigated conditions (Table 3). The mean grain yield was decreased by $30 \%$ in stress condition compare to non-stress condition over two years (Table 3). These results provide also possibility of select genotypes under both stress and non-stress conditions for high yield potential and drought tolerance. According to mean yield of two years for irrigation condition, G7 (SEN-DER), G4 and G10 (SEN-DER) showed best performances with 6.83; 6.80 and $6.74 \mathrm{t} \mathrm{ha}^{-1}$ respectively (Table 3). For mean yield in rainfall condition the highest yield were given by synthetic derived bread wheat genotypes G10, G7 and G 8 with 5.50; 4.98 and $4.76 \mathrm{t} \mathrm{ha}^{-1}$ respectively. These results indicated that genotypes derived from synthetic wheat genotypes G7 and G10 had high yield potential also tolerant against to water limited conditions.

According to average of two years, plant height was reduced $13.8 \mathrm{~cm}(12.1 \%)$ compare to irrigated condition (Table 4). The less plant height reduction is indirect indicator of tolerance for drought (Mursalova et al., 2015). Plant height were positively correlated with grain yield in rain-fed condition $\left(\mathrm{r}=0.67^{*}\right)$ and grain yield in irrigated condition $(\mathrm{r}=$ $0.50 \mathrm{~ns}$ ) (Table 7). Genotypes originated from synthetic wheats G7 and G10 showed low plant height reduction and also their yield were highest (Table 4). Average of heading days were 119 days in irrigation condition and 116 stress condition. Correlation between grain yield and heading days in water limited condition and irrigation conditions was 
negative, which means that earliness provide tolerance against to drought or provide escape from drought stress effect. Mean number spike $\mathrm{m}^{-2}$ was 541 in irrigation condition and 422 in rainfall condition over two years, also positive correlation was determined between NS and grain yield in both irrigation $(\mathrm{r}=67 * *)$ and rainfall condition $(\mathrm{r}=0.66)$ (Table 7). The mean of TKW were $36.6 \mathrm{~g}$ in irrigated and $31.4 \mathrm{~g}$ in rainfall conditions, and $14.1 \%$ reduction was recorded for TKW compare to irrigated condition. Mean of the number seed in spike that contribute grain yield were $33.2 \mathrm{seed} / \mathrm{spike}$ in irrigated and 29.8 seed/spike in rain-fed conditions, also positive and significant was determined among NSS and grain yield in irrigated $\left(\mathrm{r}=0.81^{* *}\right)$ and rain-fed conditions $\left(\mathrm{r}=0.54^{*}\right)($ Table 7$)$.

Table 2. Mean squares of investigated traits of 12 wheat genotypes

\begin{tabular}{|c|c|c|c|c|c|c|c|c|c|}
\hline Source & $\mathrm{DF}$ & GY & TKW & NS & NGS & HD & $\mathrm{PH}$ & Spad & Prt \\
\hline \multicolumn{10}{|l|}{ Stress conditions } \\
\hline Year (Yr) & 1 & $52.2 * *$ & $682 * *$ & $111657 * *$ & $392 * *$ & $1743 * *$ & $938 * *$ & $155.0 * *$ & $119.3 * *$ \\
\hline $\operatorname{Rep}(\mathrm{Yr})$ & 6 & 1.3 & 1.3 & 228.2 & 0.85 & 0.73 & 31.30 & 10.3 & 0.97 \\
\hline Genotype (Gen) & 11 & $3.0 * *$ & $64.7 * *$ & $11857.7 * *$ & $40.4 * *$ & $57.96 * *$ & $250 * *$ & $29.5^{*}$ & $3.92 * *$ \\
\hline Yr*Gen & 11 & $1.4 * *$ & $29.7 * *$ & 1054.1 & $13.7 * *$ & $12.51 * *$ & $221 * *$ & 8.1 & $4.40 * *$ \\
\hline Error & 66 & 2.0 & 0.96 & 645.2 & 1.7 & 0.26 & 18.9 & 15.3 & 0.32 \\
\hline $\mathrm{R} 2(\%)$ & & 0.84 & 0.96 & 0.86 & 0.9 & 0.99 & 0.83 & 0.39 & 0.91 \\
\hline $\mathrm{CV}(\%)$ & & 13.4 & 3.1 & 0.6 & 4.3 & 0.5 & 4.30 & 10.7 & 4.7 \\
\hline \multicolumn{10}{|l|}{ Non-stress cond. } \\
\hline Year (Yr) & 1 & $73.5 * *$ & $882 * *$ & $79063 * *$ & 121.5 & $18.64 * *$ & 551 & $221.4^{*}$ & $0.18 \mathrm{~ns}$ \\
\hline $\operatorname{Rep}(\mathrm{Yr})$ & 6 & 0.23 & 1.06 & $1797 \mathrm{~ns}$ & 0.97 & 0.34 & 8.2 & 14.5 & 1.05 \\
\hline Genotype (Gen) & 11 & $4.37 * *$ & $60.1 * *$ & $20447 * *$ & $49.7 * *$ & $61.5 * *$ & $56 * *$ & 32.0 & $1.38 * *$ \\
\hline Yr*Gen & 11 & $1.23 * *$ & $6.1 * *$ & $4039 * *$ & $12.3^{* *}$ & $7.6^{* *}$ & $27 * *$ & 6.7 & $0.76^{* *}$ \\
\hline Error & 66 & 1.56 & 0.86 & 838.2 & 1.29 & 0.42 & 7.97 & 17.9 & 0.15 \\
\hline R2 (\%) & & 0.92 & 0.96 & 0.87 & 0.91 & 0.98 & 0.75 & 0.4 & 0.75 \\
\hline $\mathrm{CV}(\%)$ & & 6.9 & 2.5 & 5.5 & 3.4 & 0.6 & 2.5 & 9.9 & 3.3 \\
\hline
\end{tabular}

* : significant at level 0.05, **: significant at level 0.01, GY: Grain yield, NS: Number spike, NGS: Number grain in spike, TKW: Thousand kernel weight, HD: Heading days, PH: Plant height, Spad: Chrolophil content, Prt: Protein content

\section{Drought Tolerance Indices}

According to drought indices that used for discriminating of genotypes (Table 5); G7, G8, G10 and G11 were determined as a candidate drought tolerant genotypes with their small values of SSI, TOL, ATI, SSPI and high values of STI, GMP, MP, HM, YSI, YI, DI, SNPI. Also, G5 seem to be drought tolerant according to YSI results, but its yield performance in both irrigated and rainfall conditions was lower than other genotypes. For TOL G3, G4, G6 and G9 were highly sensitive genotypes. Although G1 and G5 seem to be tolerant genotypes according to TOL, ATI and SSPI values, but their productivity under irrigation conditions were limited. G1, G5, G9 and G12 were also determined as a drought sensitive genotypes for GMP, MP, HM and YI. G4 had one of highest grain yield in irrigated condition but it's yield in rainfall was limited. According to stress susceptible index (SSI) G1 (Aşure; landrace) and G11 (Sorık; landrace) were drought resistance but they did not give high yield performance in stress condition, because of their limited yield potential.

Correlation analysis between grain yield under two conditions and drought tolerant indices (Table 6) indicated that grain yield in non-stress conditions were correlated with 
Ys ( $\left.\mathrm{r}=0.72^{* *}\right)$, SSI $(\mathrm{r}=0.26 \mathrm{~ns})$, STI $\left(0.89^{* *}\right)$, TOL $\left(\mathrm{r}=0.58^{*}\right)$, GMP $\left(\mathrm{r}=0.91^{* *}\right)$, MP $(0.94 * *), \mathrm{HM}\left(\mathrm{r}=0.88^{* *}\right)$, YI $(\mathrm{r}=0.72 * *)$ ATI $\left(0.80^{* *}\right)$ and SSPI $\left(0.59^{*}\right)$. Also, high and significant correlation were determined between grain yield in stress conditions (Ys) and SSI $\left(\mathrm{r}=-0.48^{*}\right)$, STI $\left(\mathrm{r}=0.95^{* *}\right)$, GMP $\left(\mathrm{r}=0.94^{* *}\right)$, MP $(\mathrm{r}=0.91)$, HM $(\mathrm{r}=$ $\left.0.96^{* *}\right)$, YSI $\left(\mathrm{r}=0.50^{* *}\right)$, YI $\left(\mathrm{r}=0.97^{* *}\right)$, DI $\left(\mathrm{r}=0.93^{* *}\right)$ and SNPI $\left(\mathrm{r}=0.95^{* *}\right)$.

Table 3. Grain yield $\left(\mathrm{t} h \mathrm{~h}^{-1}\right)$ of wheat genotypes in both conditions and reduction of yield

\begin{tabular}{llllllllll}
\hline \multirow{2}{*}{ Genotypes } & \multicolumn{3}{c}{ Season of 2013-2014 } & \multicolumn{3}{c}{ Season of 2014-2015 } & \multicolumn{3}{c}{ Average of Two Years } \\
\cline { 2 - 9 } & SIR & NIR & R\% & SIR & NIR & R\% & SIR & NIR & R\% \\
\hline G1 & 3.70 & 2.32 & 37 & 5.88 & 4.60 & 22 & 4.79 & 3.46 & 28 \\
G2 & 5.45 & 3.75 & 31 & 7.30 & 4.98 & 32 & 6.38 & 4.37 & 32 \\
G3 & 5.89 & 3.35 & 43 & 6.90 & 4.49 & 35 & 6.39 & 3.92 & 39 \\
G4 & 6.49 & 3.69 & 43 & 7.11 & 4.41 & 38 & 6.80 & 4.05 & 40 \\
G5 & 3.09 & 2.01 & 35 & 6.03 & 5.13 & 15 & 4.56 & 3.57 & 22 \\
G6 & 5.56 & 3.60 & 35 & 6.75 & 4.47 & 34 & 6.16 & 4.03 & 34 \\
G7 & 6.39 & 4.87 & 24 & 7.27 & 5.09 & 30 & 6.83 & 4.98 & 27 \\
G8 & 5.35 & 3.99 & 25 & 7.52 & 5.54 & 26 & 6.43 & 4.77 & 26 \\
G9 & 4.51 & 2.61 & 42 & 7.62 & 5.12 & 33 & 6.07 & 3.86 & 36 \\
G10 & 5.89 & 4.74 & 19 & 7.59 & 6.25 & 18 & 6.74 & 5.50 & 18 \\
G11 & 4.98 & 3.61 & 28 & 6.96 & 5.39 & 22 & 5.97 & 4.50 & 25 \\
G12 & 4.94 & 3.39 & 32 & 6.33 & 4.17 & 34 & 5.64 & 3.78 & 33 \\
\hline Mean & $5.19 \mathrm{~A}$ & $3.49 \mathrm{~B}$ & 33 & $6.94 \mathrm{~A}$ & $4.97 \mathrm{~B}$ & 28 & $6.06 \mathrm{~A}$ & $4.23 \mathrm{~B}$ & 30 \\
Lsd & $0.48 * *$ & $0.52 * *$ & & $0.70 * *$ & $1.03 * *$ & & $0.56 * *$ & $0.42 * *$ & \\
\hline
\end{tabular}

SIR: Supplemented irrigated, NIR: Non-irrigated, * : significant at level 0.05, **: significant at level 0.01, R: Reduction

\section{Evaluation of investigated traits and drought indices by GGE biplot analysis}

The GGE biplot for ten drought tolerance indices of twelve bread wheat genotypes showed that PC1 explained 59.86\% and PC2 explained 39.90\% of the total variation (Fig. 1). According to results YI, YSI, DI and SNPI were highly correlated with yield in rainfall conditions (Ys), while yield in both irrigation and rain-fed conditions were correlated with GMP, HM, MP and STI. Abiotic stress index (ATI), TOL, SSPI and SSI had a negative correlation with Ys, hence they can be discarded for determining drought tolerance genotypes. The GGE biplot for observed traits of twelve bread wheat genotypes in rain-fed conditions, $38.62 \%$ of variation explained by PC1 and $25.79 \%$ by PC2 (Fig. 2). The total variation in irrigated conditions was $60.56 \%$ that of $37.96 \%$ explained by PC1 and $22.66 \%$ by PC2. Examined traits were divided into three groups in both rain-fed and irrigated conditions, which means that traits in the same group correlated each other. According to relationship between traits in rain-fed condition grain yield (Ys), NSS, PH, TKW were similar and included in first group, NS, PRTC and SPAD were strongly correlated each other and included the second group and HD included third group. In irrigation condition, grain yield (Yp), NSS, PH and TKW strongly correlated traits that included in first group, PRTC, NS included second group and HD and SPAD included third group (Fig. 3). Plant height (PH), number seed in spike (NSS) and thousand kernel weight (TKW) were correlated with grain yield in both conditions. Heading days (HD) correlated as the negatively with grain yield in both conditions. 
Table 4. Investigated traits of genotypes (averaged over 2 years)

\begin{tabular}{|c|c|c|c|c|c|c|c|c|c|c|c|c|c|c|c|c|c|c|c|c|}
\hline \multirow{2}{*}{ Genotypes } & \multicolumn{3}{|c|}{ TKW } & \multicolumn{3}{|c|}{ NS } & \multicolumn{3}{|c|}{ NGS } & \multicolumn{3}{|c|}{ HD } & \multicolumn{3}{|c|}{$\mathrm{PH}$} & \multicolumn{3}{|c|}{ SPAD } & \multicolumn{2}{|l|}{ PRT } \\
\hline & SIR & NIR & $\% \mathrm{R}$ & SIR & NIR & $\% \mathrm{R}$ & SIR & NIR & $\% \mathrm{R}$ & SIR & NIR & $\% \mathrm{R}$ & SIR & NIR & $\% \mathrm{R}$ & SIR & NIR & $\% \mathrm{R}$ & SIR & NIR \\
\hline G1 & 39.3 & 34.7 & 11.8 & 489 & 416 & 15 & 28.5 & 24.3 & 14.9 & 117.0 & 113.8 & 2.8 & 114.4 & 101.3 & 11.5 & 40.7 & 36.4 & 10.6 & 12.4 & 12.9 \\
\hline G2 & 36.2 & 30.0 & 17.2 & 535 & 435 & 19 & 35.1 & 32.0 & 8.9 & 114.3 & 111.8 & 2.2 & 113.1 & 104.4 & 7.7 & 42.1 & 39.2 & 6.9 & 12.3 & 12.9 \\
\hline G3 & 37.9 & 33.3 & 12.1 & 543 & 397 & 27 & 33.3 & 30.3 & 9.0 & 116.6 & 114.4 & 1.9 & 113.8 & 96.9 & 14.8 & 43.9 & 38.4 & 12.5 & 12.5 & 12.7 \\
\hline G4 & 36.5 & 31.8 & 12.8 & 533 & 380 & 29 & 38.1 & 33.0 & 13.4 & 118.4 & 114.8 & 3.1 & 110.6 & 98.8 & 10.7 & 39.8 & 34.5 & 13.5 & 12.1 & 12.3 \\
\hline G5 & 32.8 & 29.5 & 10.0 & 448 & 366 & 18 & 30.1 & 28.9 & 4.1 & 121.1 & 118.6 & 2.1 & 105.6 & 89.4 & 15.4 & 43.3 & 36.5 & 15.7 & 12.6 & 12.1 \\
\hline G6 & 31.2 & 26.8 & 14.2 & 625 & 475 & 24 & 34.1 & 28.9 & 15.4 & 117.3 & 114.8 & 2.1 & 116.3 & 103.1 & 11.3 & 43.8 & 39.9 & 8.9 & 12.9 & 13.6 \\
\hline G7 & 36.7 & 31.3 & 14.6 & 628 & 471 & 25 & 34.5 & 30.1 & 12.7 & 118.0 & 115.0 & 2.5 & 118.1 & 106.9 & 9.5 & 39.9 & 34.9 & 12.5 & 12.9 & 12.8 \\
\hline G8 & 36.3 & 31.3 & 13.8 & 564 & 462 & 18 & 34.0 & 30.4 & 10.5 & 122.5 & 120.1 & 1.9 & 112.5 & 99.4 & 11.7 & 44.1 & 37.6 & 14.9 & 12.1 & 12.4 \\
\hline G9 & 35.5 & 26.8 & 24.6 & 570 & 432 & 24 & 31.4 & 29.0 & 7.6 & 122.1 & 119.4 & 2.3 & 112.5 & 93.8 & 16.7 & 45.3 & 35.0 & 22.7 & 12.4 & 12.7 \\
\hline G10 & 41.8 & 35.6 & 14.8 & 544 & 467 & 14 & 33.0 & 31.1 & 5.9 & 115.4 & 112.6 & 2.4 & 116.9 & 109.4 & 6.4 & 43.9 & 38.4 & 12.6 & 12.3 & 12.3 \\
\hline G11 & 37.0 & 34.3 & 7.4 & 476 & 401 & 16 & 34.1 & 31.6 & 7.3 & 116.6 & 114.3 & 2.0 & 112.5 & 96.3 & 14.4 & 43.2 & 34.3 & 20.5 & 12.0 & 12.2 \\
\hline G12 & 37.6 & 31.6 & 16.0 & 536 & 368 & 31 & 32.0 & 28.6 & 10.5 & 121.6 & 117.5 & 3.4 & 109.4 & 100.6 & 8.0 & 46.1 & 36.1 & 21.7 & 12.3 & 12.2 \\
\hline Mean & $36.6 \mathrm{~A}$ & $31.4 \mathrm{~B}$ & 14.1 & $541 \mathrm{~A}$ & $422 B$ & 22 & $33.2 \mathrm{~A}$ & $29.9 \mathrm{~B}$ & 10.0 & $118 \mathrm{~A}$ & $116 \mathrm{~B}$ & 2.4 & $113 \mathrm{~A}$ & $100 \mathrm{~B}$ & 11.5 & $43 \mathrm{~A}$ & $36.8 \mathrm{~B}$ & 14.4 & 12.4 & 12.6 \\
\hline Lsd & $0.92 * *$ & $0.98 * *$ & & $28.9 * *$ & $25.4 * *$ & & $1.1^{* *}$ & $1.3 * *$ & & $0.64 * *$ & $0.56^{* *}$ & & $2.8 * *$ & $4.4^{* *}$ & & $4.2 * *$ & $3.9 * *$ & & $0.4 * *$ & $0.3 * *$ \\
\hline
\end{tabular}

*: significant at level 0.05, **: significant at level 0.01, TKW: Thousand kernel weight, NS: Number spike, NGS: Number grain in spike, HD: Heading days, PH: Plant height, Spad: Crolofil content, Prt: Protein content 


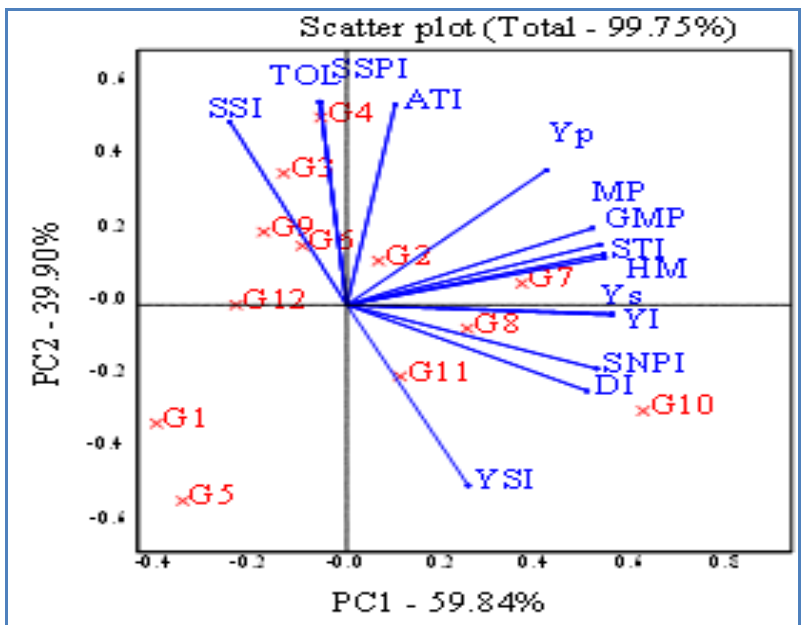

Figure 1. Biplot based on first two principal component axes (PC1 and PC2).

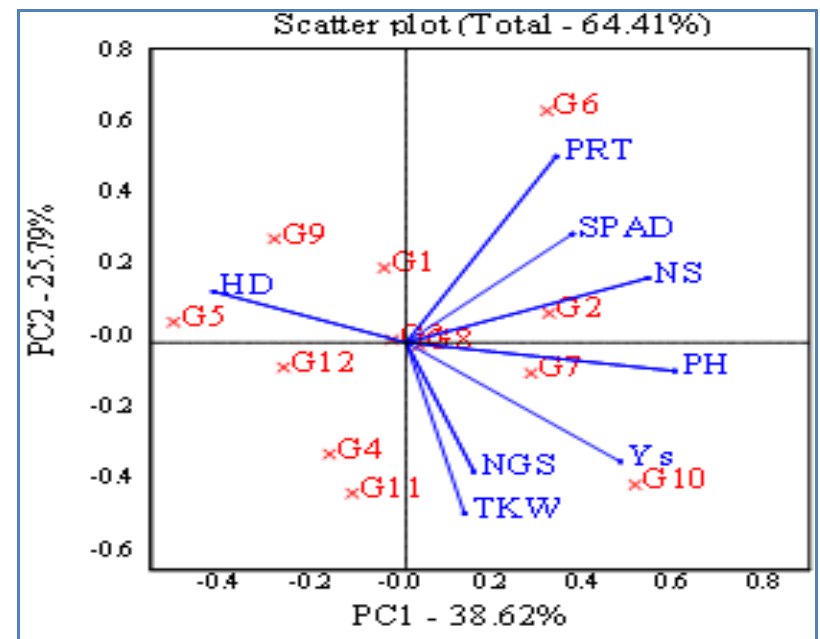

Figure 2. Biplot based on first two principal component axes (PC1 and 2) for traits of genotypes in rain-fed conditions.

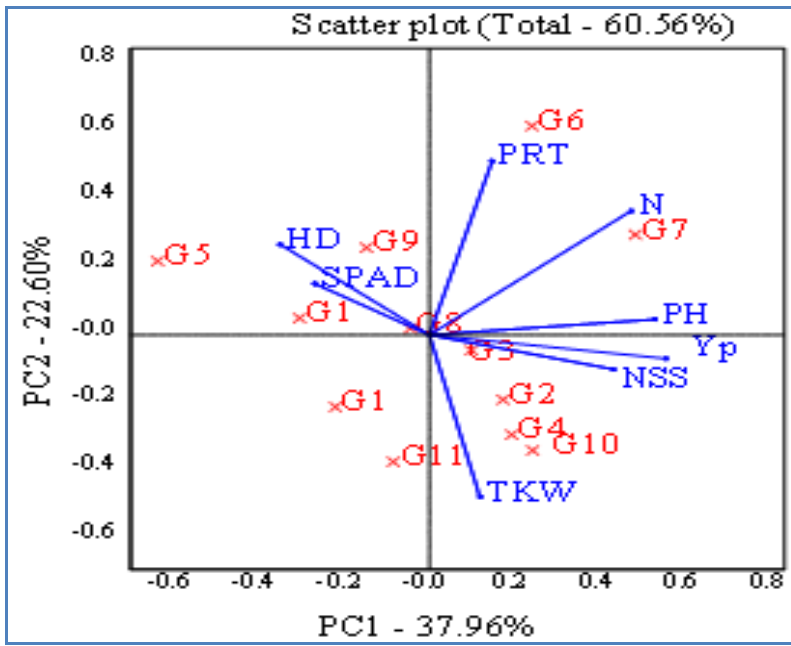

Figure 3. Biplot based on first two principal component axes (PC1 and 2) for traits of genotypes in irrigated conditions. 
Table 5. Drought indices of 12 wheat genotypes (averaged over 2 years)

\begin{tabular}{|c|c|c|c|c|c|c|c|c|c|c|c|c|c|c|}
\hline \multirow[b]{2}{*}{ Code } & \multicolumn{14}{|c|}{ Drought Indices } \\
\hline & Yp & Ys & SSI & STI & TOL & GMP & MP & $\mathrm{HM}$ & YSI & $\mathrm{YI}$ & DI & ATI & SSPI & SNPI \\
\hline G1 & 4.79 & 3.46 & 0.92 & 0.45 & 1.33 & 4.07 & 4.1 & 4.02 & 0.72 & 0.82 & 10.6 & 3.0 & 11.0 & 18.8 \\
\hline G2 & 6.38 & 4.37 & 1.04 & 0.76 & 2.01 & 5.28 & 5.4 & 5.18 & 0.68 & 1.03 & 12.7 & 5.8 & 16.6 & 25.5 \\
\hline G3 & 6.39 & 3.92 & 1.28 & 0.68 & 2.48 & 5.00 & 5.2 & 4.86 & 0.61 & 0.93 & 10.2 & 6.8 & 20.4 & 20.2 \\
\hline G4 & 6.80 & 4.05 & 1.34 & 0.75 & 2.75 & 5.25 & 5.4 & 5.08 & 0.60 & 0.96 & 10.2 & 7.9 & 22.7 & 21.0 \\
\hline G5 & 4.56 & 3.57 & 0.72 & 0.44 & 0.99 & 4.03 & 4.1 & 4.00 & 0.78 & 0.84 & 11.8 & 2.2 & 8.2 & 21.8 \\
\hline G6 & 6.16 & 4.03 & 1.14 & 0.68 & 2.12 & 4.98 & 5.1 & 4.88 & 0.66 & 0.95 & 11.2 & 5.8 & 17.5 & 21.9 \\
\hline G7 & 6.83 & 4.98 & 0.90 & 0.92 & 1.85 & 5.83 & 5.9 & 5.76 & 0.73 & 1.18 & 15.4 & 5.9 & 15.3 & 32.9 \\
\hline G8 & 6.43 & 4.77 & 0.86 & 0.83 & 1.67 & 5.54 & 5.6 & 5.48 & 0.74 & 1.13 & 14.9 & 5.0 & 13.7 & 31.3 \\
\hline G9 & 6.07 & 3.86 & 1.20 & 0.64 & 2.20 & 4.84 & 5.0 & 4.72 & 0.64 & 0.91 & 10.4 & 5.8 & 18.2 & 20.2 \\
\hline G10 & 6.74 & 5.50 & 0.61 & 1.01 & 1.24 & 6.09 & 6.1 & 6.05 & 0.82 & 1.30 & 19.0 & 4.1 & 10.3 & 44.8 \\
\hline G11 & 5.97 & 4.50 & 0.82 & 0.73 & 1.47 & 5.18 & 5.2 & 5.13 & 0.75 & 1.06 & 14.4 & 4.2 & 12.1 & 29.3 \\
\hline G12 & 5.64 & 3.78 & 1.09 & 0.58 & 1.86 & 4.61 & 4.7 & 4.52 & 0.67 & 0.89 & 10.7 & 4.7 & 15.3 & 20.2 \\
\hline
\end{tabular}

Table 6. Correlation between drought tolerance indices and grain yield in both conditions based on mean of 2 years

\begin{tabular}{|c|c|c|c|c|c|c|c|c|c|c|c|c|c|}
\hline & Ys & SSI & STI & TOL & GMP & MP & HM & YSI & YI & DI & ATI & SSPI & SNPI \\
\hline Yp & $0.72 * *$ & 0.26 & $0.89^{* *}$ & $0.58^{*}$ & 0.91 ** & $0.94 * *$ & $0.88^{* *}$ & -0.24 & $0.72^{* *}$ & 0.39 & $0.80^{* *}$ & $0.59^{*}$ & $0.49^{*}$ \\
\hline Ys & 1 & -0.48 & $0.95 * *$ & -0.15 & $0.94 * *$ & $0.91 * *$ & $0.96^{* *}$ & $0.50^{*}$ & $0.97^{* *}$ & $0.93^{* *}$ & 0.14 & -0.15 & $0.95^{* *}$ \\
\hline
\end{tabular}

Table 7. Correlation between investigated traits and grain yield in irrigated $(Y p)$ and nonirrigated $(Y s)$ based on mean of 2 years

\begin{tabular}{lllllllll}
\hline & Ys & NS & PH & HD & TKW & NGS & SPAD & PRT \\
\hline Yp & $0.72 * *$ & $0.67 * *$ & $0.45 \mathrm{~ns}$ & $-0.28 \mathrm{~ns}$ & $0.22 \mathrm{~ns}$ & $0.81 * *$ & $-0.15 \mathrm{~ns}$ & $-0.16 \mathrm{~ns}$ \\
$\mathrm{Ys}$ & & $0.66 * *$ & $0.67 * *$ & $-0.27 \mathrm{~ns}$ & $0.33 \mathrm{~ns}$ & $0.54 *$ & $-0.08 \mathrm{~ns}$ & $-0.10 \mathrm{~ns}$ \\
\hline
\end{tabular}

*: Significant at level 0.05, **: Significant at level 0.01, ns: Non significant, NS: Number spike, NGS: Number grain in spike, TKW: Thousand kernel weight, HD: Heading days, PH: Plant height, Spad: Crolofil content, Prt: Protein content, Yp: Yield in irrigated cond., Ys: Yield in non-irrigated conditions

\section{Discussion}

Wheat breeder have been evaluating wheat genotypes in irrigated and rainfall conditions to discriminate genotypes regarding to level of drought tolerance with many drought indices. Fernandez (1992) reported that genotypes can be divided in to four group according to their yield in stress and non-stress conditions: genotypes that have high yield under both stress and non-stress (group A), genotypes with high yield response in nonstress (group B), or stress condition (group C) and the last genotypes with low yield performance in both conditions (group D). Three synthetic derived genotypes (G7, G8 and G10) and landrace G11 (Sork) were the most productive in both conditions, thus, these genotypes stayed into group A. It was reported that wheat genotypes derived from 
synthetic wheat originated from CIMMYT were superior genotypes than modern bread wheat genotypes in mega environments yield trials regarding to grain yield and quality traits (Lage et al., 1998). Also, SEN-DER bread wheat genotypes have novel genes/traits related to biotic and abiotic stress, such as drought stress and rust diseases (Mujeeb-Kazi et al., 2008). In study performed at Mexico reported that synthetic derived wheat lines showed 26\% more grain yield than parental hexzaploid wheat under drought stress (Lopes and Reynolds, 2011). Landrace genotypes G1 (Aşure), G5 (Karakılçı) and G9 (SENDER) can be defined as group D genotypes, because of their poor yield performance in both conditions. Modern wheat genotypes (G2, G3, G4, G6) were defined as Group B, since their high yield performance in irrigation condition and poor yield in rainfall condition. Two landrace genotypes G1 (Aşure), G5 (Karakılçık) showed poor performance in both irrigated and rainfall conditions, while the other two landrace genotypes G11 (Sorkk) and G12 (Bejireş) had a appreciate grain yield in both conditions. Aynehband et al. (2011) indicated that modern bread wheat genotypes are more adapted to favorable conditions, while landrace have poor yield in favorable conditions because of their lodging problem and lower response to nitrogen, even their yield under drought stress is appreciate On the other hand, wheat genotypes which carry dwarf genes provide lodging resistance, high nitrogen efficiency and more grain yield in the last decades (Mursalova et al., 2015).

Our results based on correlation analysis indicated that selection based on indices (STI, GMP, MP, HM, YSI and YI) may increase yield in both conditions and using DI and SNPI as parameters may contribute yield increasing in drought stress conditions. Similar results reported by Mohammadi et al. (2011) indicated that GMP, MP and STI were suitable drought indices to identify RILs producing high yield in stress and nonstress conditions. Also, it was found significant and high correlations between HM, YI, GMP in investigation related to exotic wheat genotypes (Anvar et al., 2011). TOL correlated positively with Yp and negatively with Ys which means that selection based on TOL will increase grain yield for irrigated conditions. Similar results concluded with investigation on landraces and modern wheat genotypes in Central Anatolia conditions, Turkey (Akçura et al., 2011a). Farshadfar et al. (2012) observed non-significant correlations between TOL, SSI, SSPI and yield in stress conditions; and high and significant correlation between DI and Ys.

Biplot analysis were also used to identify relation between drought tolerant indices and grain yield in both conditions (Fig. 1). For drought tolerance indices, 59.84\% of variation explained by PC1 correlated with GMP, HM, MP, Yp, Ys, YSI, YI, DI and SNPI (Fig. 1). The PC2 explained 39.90\% of total variation and highly correlated with TOL, SSI and SSPI (Fig. 1). Genotypes with high PCA1 and low PCA2 are more productive under stress and non-stress conditions (Gauch, 2006). Thus, SEN-DER genotypes G7, G8 and G10, and also modern wheat genotype G2 (Tekin) are superior genotypes with their high PC1 and low PC2 for both irrigated and rain-fed conditions (Fig. 1). According to biplot analysis, YI, YSI, DI and SNPI were highly correlated with grain yield in rainfall conditions (Ys), these result suggested that selection based on these indices will provide increasing grain yield in stress conditions, while grain yield in both irrigation and rain-fed conditions were correlated with GMP, HM, MP and STI, which means that selection based on these indices will resulted increasing grain yield in both conditions. TOL and SSI positively correlated with Yp (grain yield in irrigated condition) and negatively with Ys (grain yield in rainfed condition). Biplot 
analyse were discriminated that G7, G8, G10 and G11 as the most drought tolerance genotypes.

Correlation between investigated traits in both irrigated and rain-fed conditions and grain yield was displayed by biplot (Fig. 2 and Fig. 3). Total variations in rain-fed conditions $(64.41 \%)$ was more than irrigated conditions $(60.56 \%)$, which means that genotypes showed more variable reactions in stress conditions. According to results of biplot grain yield in both conditions were strongly correlated with plant height $(\mathrm{PH})$, numbers seed in spike (NSS) and thousand kernel weight (TKW), these results indicated that using traits related to grain yield in stress conditions can contribute to improving and determining of drought tolerance genotypes in breeding programs. Similar results reported by Jatav and Kandalkar (2014) claim that genotypes with lower plant height, thousand kernel weight and number seed in spike reduction in stress conditions are more productive and tolerant against to drought. It was reported that the reason low yield in stress condition was due to reduction in number seed in spike and number of the spike in square meter (Akçura et al., 2011a). SEN-DER., wheat genotypes G10 and G7 also modern wheat genotype G2 (Tekin) were most productive in rain-fed conditions according to biplot results (Fig. 2). Biplot results (Fig. 3), also indicated that grain yield in irrigated conditions were correlated with numbers seed in spike (NSS) and thousand kernel weight (TKW). According to results obtained from biplot indicated that modern wheat genotype G4 (Ceyhan-99) and genotype G10 (SEN-DER) were most productive, in irrigated conditions (Fig. 3). Aktaş (2014) reported that Ceyhan-99 cultivar is largely cultivated in Turkey and more adaptable for favorable conditions.

\section{Conclusion}

According to pairwaise correlation, biplot analysis YI, YSI, DI and SNPI drought indices can be used as parameter in breeding programs to increase grain yield in stress conditions and GMP, HM, MP and STI in both stress and non-stress conditions. Also, it was concluded that genotypes derived from synthetic wheats valuable germplasm because of high performance of SEN-DER., genotypes G10 and G7. Also, results indicated that plant height, number seed in spikes and number spikes in square meter is important traits that can be used criterions to improving drought tolerant genotypes.

Acknowledgements. This study was financially supported by the Minister of the Agricultural Research, Turkey (Proj. no. TAGEM. TR. 2012235875), thanks to GAP Int. Agr. Res. Training Center, Diyarbakir.

\section{REFERENCES}

[1] Akçura, M., Partigoç, F., Kaya, Y. (2011a): Evaluating of drought stress tolerance based on selection indices in Turkish bread wheat landraces. - The Journal of Animal \& Plant Sciences 21(4): 700-709

[2] Akçura, M. (2011b): The relationships of some traits in Turkish winter bread wheat landraces. - Turkısh Journal Agriculture 35(2): 115-125.

[3] Aktaş, H. (2014): Investigation of quality stability and micro elements content of some bread wheat varieties in southeast Anatolia region conditions. - Mustafa Kemal University, Field Crop Department. Phd thesis. pp.269. 
[4] Anwar, J., Ghulam, M.S., Makhdoom, H., Javed, A., Mujahid, H., Munir, M. (2011): Drought tolerance indices and their correlation with yield in exotic wheat genotypes. Pakistan Journal of Botany 43(3): 15271530.

[5] Aynehband, A., Moezi, A.A., Sabet, M. (2011): The comparison of nitrogen use efficiencies in old and modern wheat cultivars: Agroecological results. - AmericanEurasian Journal of Agriculture \& Environment Science 10(4): 574-586

[6] Bouslama, M., Schapaugh, W.T. (1984): Stress tolerance in soybean. 1- Evaluation of three screening techniques for heat and drought tolerance.- Crop Science 24: 933-937.

[7] Chakherchaman, S.A., Mostafaei, H., Imanparast, L., Eivazian, M.R. (2009): Evaluation of drought tolerance in lentil advanced genotypes in Ardabil region. - Iran Journal Food Agriculture Environment 7 (3-4): 283-288.

[8] Dixon, J., Braun, H.J. Crouch J.H. (2009): Overview: transitioning wheat research to serve the future needs of the developing world. In: Dixon J, Braun H-J, Kosina P, Crouch J, (eds). Wheat facts and futures 2009. Mexico, D.F: CIMMYT.

[9] Farshadfar, E., Jamshidi, B., Aghaee, M. (2012): Biplot analysis of drought tolerance indicators in bread wheat landraces of Iran. -International Journal of Agriculture and Crop Science 4: 226-233.

[10] Fernandez, G.C.J. (1992): Effective selection criteria for assessing plant stress tolerance. In: Proceedings of the international symposium on adaptation of vegetable and other food crops in temperature and water stress. - Taiwan 257-270.

[11] Gauch, H.G. (2006): Statistical Analysis of Yield Trials by AMMI and GGE. - Crop Science 46: 1488-1500

[12] Gavuzzi, P., Rizza, F., Palumbo, M., Campaline, R.G., Ricciardi, G.L., Borghi, B. (1997): Evaluation of field and laboratory predictors of drought and heat tolerance in winter cereals. - Plant Science 77: 523-531

[13] GENSTAT. (2009): GenStat for Windows (12th Edition) Introduction. VSN International, Hemel Hempstead.

[14] Hossain, A.B.S., Sears, A.G., Cox, T.S., Paulsen, G.M. (1990):. Desiccation tolerance and its relationship to assimilate partitioning in winter wheat. - Crop Science 30: 622-627.

[15] Jatav, S.K., Kandalkar, V.S. (2014): Assessment of wheat genotypes for yield potential and stress adaptation. - Journal of Wheat Research 6(1): 29-36

[16] Koh-Banerjee, P., Franz, M., Sampson, L., Liu, S., Jacobs, D., Spiegelman, D., Willett, W., Rimm, E. (2004): Changes in whole-grain, bran, and cereal fiber consumption in relation to 8-y weight gain among men. - American Journal of Clinical Nutrition 80: $1237-1245$.

[17] Lage, J., Trethowan, R.M., Hernandez, E. (2008): Identification of site similarities in western and central Asia using CIMMYT international wheat yield data. - Plant Breeding 127(4): 350-354

[18] Lan, J. (1998): Comparison of evaluating methods for agronomic drought resistance in crops. Acta Agriculture Bor-occid Sinic 7: 85-87.

[19] Lopes, M.S., Reynolds, M.P. (2011): Drought adaptive traits and wide adaptation in elite lines derived from resynthesized hexaploid wheat. - Crop science 51: 1617-1626

[20] Mohammadi, M., Karimizadeh, R., Abdipour, M. (2011): Evaluation of drought tolerance in bread wheat genotypes under dryland and supplemental irrigation conditions. Australian Journal of Crop Sciences 5 (4): 487-493.

[21] Moosavi, S.S., Yazdi, S.B., Naghavi, M.R., Zali, A.A., Dashti, H., Pourshahbazi, A. (2008): Introduction of new indices to identify relative drought tolerance and resistance in wheat genotypes. - Desert 12: 165-178.

[22] Mujeeb-Kazi, A., Gul, A., Farooq, M., Rizwan, S., Ahmad, I. (2008): Rebirth of synthetic hexaploids with global implications for wheat improvement. - Australia Journal of Agriculture Research 59: 391-398. 
[23] Mursalova, J., Akprov, Z., Ojaghi, J., Eldarov, M., Belen, S., Gummadov, N., Morgounov, A. (2015): Evaluation of drought tolerance of winter bread wheat genotypes under drip irrigation and rain-fed conditions. - Turkish Journal Agriculture 39: 1407-152

[24] Nouri, A., Etminan, A., Teixeira da Silva, J.A., Mohammadi, R. (2011): Assessment of yield, yield-related traits and drought tolerance of durum wheat genotypes (Triticum turjidum var. durum Desf.). - Australian Journal Crop Science 5(1): 8-16.

[25] Ogbonnaya, F.C., Imtiaz, F.C., Bariana, H.S., McLean, M., Shankar, M.M. (2008): Mining synthetic hexaploids for multiple disease resistance to improve bread wheat. Crop and Pasture Science 59: 421-431

[26] Rajaram, S. (2001): Prospects and promise of wheat breeding in the 21st century. Euphytica 119: 3- 15.

[27] Reynolds, M.P., Rebetzke, G. (2011): Application of plant physiology in wheat breeding. In AP Bonjean, WJ Angus, M Van Ginkel, eds, The World Wheat Book: A History of Wheat Breeding 2: 877-906

[28] Rosielle, A.A., Hamblin, J. (1981): Theoretical aspects of selection for yield in stress and non- stress environment. - Crop Science 21: 943-946. 